\title{
Tidal level influence on the spawning process of the sea urchin Paracentrotus lividus (Lamarck, 1816) on a rocky shore (Bay of Biscay).
}

\author{
De Casamajor Marie-Noelle ${ }^{1,{ }^{*}}$, Mahias Jeremy ${ }^{2}$, Castets Virginie ${ }^{1}$, Caill-Milly Nathalie ${ }^{1}$, Bru Noelle ${ }^{2}$, \\ Lissardy Muriel ${ }^{1}$
}

${ }^{1}$ Ifremer, Laboratoire Ressources Halieutiques d'Aquitaine, HGS \LRHA \FED4155MIRA, UFR Côte basque, 1 allée du Parc Montaury 64600 Anglet, FED 4155 MIRA, France

2 UNIV PAU \& PAYS ADOUR, Laboratoire de Mathématiques et de leurs Applications de Pau, UMR CNRS 5142, FED 4155 MIRA, Anglet, France

*Corresponding author : Marie-Noelle de Casamajor, email address : $\underline{\text { mndecasa@ifremer.fr }}$

\begin{abstract}
:
The sea urchin Paracentrotus lividus is an important exploited resource on the Mediterranean coast and has been the subject of much research. In the Bay of Biscay, the situation is different, as some studies have been conducted on the Spanish Basque coast but few on the French part of that coast. However, the Basque coast offers favourable conditions for the development of this species, and its exploitation could be a source of potential diversification for fishermen, especially in the context of difficulties with some other resources. At the request of the managers of this coastal resource, a study was undertaken on sea urchins to improve knowledge of this stock, particularly about its biological characteristics. In this work, assessment consisted of determining the spawning process of the stock throughout the year by collecting data on sea urchin size and wet weights of the test, dry gonads and viscera. From September 2013 to September 2014, sea urchins were collected monthly at this site, from intertidal and subtidal areas, and then analysed in the laboratory. This study takes into account the tidal level in the sample design, which allows a novel highlighting of significant differences in biological characteristics between intertidal and subtidal individuals. Spawning occurs mainly during May and June, which is important knowledge for defining relevant management measures for fisheries.
\end{abstract}

\section{Highlights}

- Sea urchins biological differences considering tidal level. - Seasonal shift in the pre and post spawning between interdial and subtidal area. Ecosystemic approach to understand spawning process. New indexes used considering spherical nature of the sea urchin.

Keywords : Sea urchin, Bay of Biscay, Spawning, Tidal level, Rocky coast 


\section{Introduction}

Paracentrotus lividus is the main echinoid species exploited in Europe (Boudouresque \& Verlaque, 2013) and understanding the modalities of its reproduction appears very important for sustainable fishing management strategies. The sexes are separate, but sea urchins show no external sexual dimorphism. Maturity is reached at about 3 years, with an average diameter of 3 to $4 \mathrm{~cm}$ without spines (Grosjean, 2001; Bald et al., 2007), but growth is very dependent on environmental factors. The reproductive cycle is annual, with gonad maturation occurring in spring. The male gonad is whitish, while the female one is orange-coloured. Mature individuals simultaneously release their gametes into the water column, where fertilisation occurs. The egg is segmented to produce pelagic larvae with bilateral symmetry. After several successive stages in the water column (estimated time around 1 month), larvae settle on the bottom to metamorphose into adults (Grosjean, 2001; Lawrence, 2013). The most suitable substrates for recruitment are those covered by algae and hard materials (Gago et al., 2003); however, erect algae and seagrasses are also suitable (Boudouresque \& Verlaque, 2013). The environmental factors affecting modalities of sea urchin reproduction have been extensively covered in the literature (Martinez et al., 2001; Bronstein \& Loya, 2015). An important bibliographic synthesis of the geographic population and seasonal patterns of the reproduction of this species was conducted by Ouréns et al. (2011). Information is also available on other species of sea urchin in other regions (King et al., 1994; Brewin et al., 2000; Epherra et al., 2015).

Food availability and quality affect the growth of the sea urchin as well as the production of the gonads. Productivity and phytoplankton blooms may therefore be relevant for seasonal reproductive patterns or for recruitment (Zhedan et al., 2015). Spawning is preceded by a period of chlorophyll-a augmentation, which indicates a high phytoplankton abundance and high food availability (Bronstein \& Loya, 2015). Gonad size varies greatly according to location (Briand, 1995); for example, on the French Atlantic coast, the difficulty of accessing food resources leads to a decrease in the growth of gonads (Barillé-Boyer et al., 2004). The efficiency also depends on the nature of food, as sea urchins use more or less energy to collect, chew, digest and assimilate their food intake (Fernandez \& Caltagirone, 1998). When individuals spend substantial amounts of energy on feeding, they have less energy for metabolism for the growth of gonads (Regis, 1980). 
Hydrodynamics is the second factor that appears in the literature as important for the energy used in developing sea urchin gonads (Sellem et al., 2007). When wave action and currents are strong, the sea urchin uses more energy in metabolism, spine maintenance, and rock attachment than in reproduction (Menchaca et al., 2011). In addition, its mobility is reduced, and this limits the ability to forage for food (Sellem et al., 2007; Gianguzza et al., 2013).

As with many marine species, water temperature influences the release of gametes. Below $13^{\circ} \mathrm{C}$, gamete release is inhibited in P. lividus (Boudouresque \& Verlaque, 2013). When temperatures increase in the spring, this triggers the emission of gametes. Temperatures between 13 and $16^{\circ} \mathrm{C}$ are possible thresholds for the reproductive process (González-Irusta et al., 2010). In contrast, the temperature declines in winter are correlated with gonadal growth (Byrne, 1990; Shpigel et al., 2004). Salinity fluctuations are also a factor that may affect the reproductive cycle and spawning process. Sea urchins are stenohaline organisms (Fernandez et al., 2001); changes in salinity in sea water may therefore result in a decrease in their growth and have an indirect influence on gonad development (Basuyaux et al., 1998). Salinities below 15-20 g / L and greater than 39-40 g / L are lethal (Boudouresque \& Verlaque, 2013).

A short photoperiod and winter season increase egg and sperm production rates (Byrne, 1990). In the reproductive cycle, a photoperiod of approximately 15 hours appears to be optimal to initiate the reproductive process and the release of gametes (Pearse, 1970; Spirlet et al., 2000; Shpigel et al., 2004). Bronstein \& Loya (2015) consider that photoperiod is a secondary factor relative to the elevation of temperature in the process of spawning. Both temperature and hydrodynamic conditions can appear fluctuate from year to year. Coastal water freshening may be highly variable from one year to another, and this leads to changes in the seasonality of $P$. lividus reproduction.

The originality of the present study is that all samples come from the same location, which minimises the variability in environmental conditions, and highlights tidal conditions in both intertidal and subtidal areas. Identification of the factors that cause spawning would be helpful for the management of this species. Several researchers (Sanchez-España et al., 2004; Sellem \& Guillou, 2007; Menchaca et al., 2011; Gianguzza et al., 2013; Bronstein \& Loya, 2015) have shown the influence of a combination of environmental factors on the spawning process. The objective of the sampling strategy 
used here was therefore to identify the spawning period at these two bathymetric levels. This work describes the period of spawning over one year and examines the influences exerted on reproductive processes by the environmental conditions encountered during sampling, including temperature, seasonal photoperiod and hydrodynamic conditions.

\section{Materials and Methods}

\subsection{Sampling strategy}

The French Basque coast (southwest of the Bay of Biscay) has a bedrock composed mainly of a geomorphological "flysch facies", intersected in some places by boulder fields or by sandy beaches and estuaries (Augris et al., 2009). This coast is subject to an extensive freshwater inflow as a result of a very rainy climate, with around 1500 to $2000 \mathrm{~mm}$ of rainfall per year (Winckel et al., 2003; Usabiaga et al., 2004). In addition, outputs from sewage plants are also numerous along the shoreline and contribute to the freshening of the coastal water. The tidal regime is termed mesotidal, with an average tidal range between $1.85 \mathrm{~m}$ and $3.85 \mathrm{~m}$. The hydrodynamic conditions are characterised by the presence of high-energy waves breaking on the shore (mean height $1.8 \mathrm{~m}$ for an average period of $9.6 \mathrm{~s})$. These conditions are well known as unfavourable for the sea urchin reproductive cycle because individuals must mobilise their energy to resist the currents generated by waves and do so at the expense of gonad maturation (Jacinto et al., 2013).

The sampling strategy focused on the identification of the best period for sea urchin spawning at a given bathymetric level. Samples were collected in the municipality of Socoa, near the Bay of SaintJean-de-Luz, in the area of a sea urchin fishery (Figure 1). Changes in biological parameters during an annual cycle and between bathymetric levels were studied in individuals that were always taken at the same place (fine scale) to avoid any fluctuations that might have been caused by different environmental parameters. The two sampling stations were chosen with the same type of habitat at two bathymetric levels. The main geomorphological facies of the rocky Basque coast is the flysch, where the sea urchin shows burrowing behaviour between geological layers. At the intertidal station, sea urchins were hand-collected at low tide $\left(1^{\circ} 41.084 \mathrm{~W} ; 43^{\circ} 23.786 \mathrm{~N}\right)$. However, sea urchins sampled at this station were exposed to desiccation at each low tide, regardless of the tidal coefficient and swell height. For the subtidal station, at the bathymetric level of $-5 \mathrm{~m}$, the sea urchins were collected by 
scuba diving $\left(1^{\circ} 41.365 \mathrm{~W} ; 43^{\circ} 23.865 \mathrm{~N}\right)$. For subtidal collection, the sampling conditions were more restrictive, because waves had to be less than $1.5 \mathrm{~m}$ in height to allow access to the sampling station. For this reason, two sampling dates are missing (Table 1).

Sea urchins were sampled between September 2013 and September 2014. This collection targeted individuals with a diameter exceeding $35 \mathrm{~mm}$ to ensure sexual maturity. For each bathymetric level, 32 sea urchins were collected monthly during winter and twice a month from spring to autumn, which is supposed to be the breeding season (Table 1). Sampling was not possible for two months in the subtidal area (in January and February 2014) due to a succession of major storms, unfavourable meteorological conditions, and heavy swell.

For each sampling period, the seawater temperature (surface layer) was obtained from the Pasaia metrological station website (http://estacion.itsasnet.com/). At around $20 \mathrm{~km}$ from the sampling site this was the closest station that could provide daily seawater temperatures and was the only source of this information.

\subsection{Laboratory measurements}

Sea urchins were immediately transported to the laboratory in an opaque and hermetically-sealed cooler to prevent light or heat shock. This was especially important during the breeding season to avoid the emission of gametes during transfer. Before dissection, sampled sea urchins were blotted dry on a paper towel and individually weighed to the nearest $0.01 \mathrm{~g}$ in order to determine their individual wet mass. The test diameter at ambitus (Dt) and height (Ht) (excluding spines) of each sea urchin were then measured to the nearest $0.01 \mathrm{~mm}$ using a digital calliper. Sea urchins were dissected to remove gut contents and the five gonads. The test (with spines and the Aristotle's lantern), gonads and gut content were dried at $60{ }^{\circ} \mathrm{C}$ for $48 \mathrm{~h}$ in order to obtain the dry mass of the three biological parts of the sea urchin. All dry weight measurements were performed using an electronic balance (accuracy: 0.001 g).

\subsection{Data treatment}

A general description of variables (diameter, height and mass dry weight of the test) was made with box plots for characterisation of individuals between bathymetric levels. Non-normal data were 
analysed using the Wilcoxon-Mann-Whitney non parametric test to examine differences between the two levels.

The informative sex ratio (SR) was calculated, but no histological analysis was performed to define sex ratio, so this information is only given as an indicative parameter. Sex was defined only by observing the colour of the gonads: orange for females and whitish (light brown) for males. Because of the difficulty in performing sex determination outside the breeding season and errors that could be introduced in the absence of gonad histology, this information is presented but was not included in the analysis.

Two biological relevant indices (Menchaca et al., 2011; Ourens et al., 2012) were used to define the period of gamete release. The gonadosomatic index (GI: Gonad dry weight/Test dry weight)*100) and the repletion index (RI: Gut dry weight/Test dry weight)*100) were used to study the seasonal process of sea urchin gamete release at the two depths: intertidal and subtidal.

Gonad weight was normalised using individual size. A gonadal index GI was created as follows:

\section{GI = Gonad Dry weight $/ \mathbf{D t}^{3}$}

This GI estimates the proportion of the gonad weight relative to the diameter of individuals (Dt) and allows comparison of the differences between two samples.

A repletion index, RI, was created using the following equation:

$$
\mathrm{RI}=\text { Gut dry weight } / \mathrm{Dt}^{3}
$$

and was normalised using individual size.

Comparing changes in gonad weight with changes in gut content revealed a link between RI and gonadal development. The Pearson correlation coefficient $r^{2}$ was calculated for GI and for RI between the two tidal levels.

All tests and analyses were performed with R (http://cran.r-project.org/web/packages/index.html). The Non parametric Wilcoxon-Mann-Whitney Paired test was used for comparison between the two indices for intertidal and subtidal levels. 
165

166

167

168

169

170

171

172

173

174

175

176

177

178

179

180

181

182

183

184

185

186

187

188

189

\section{Results}

\subsection{General description of individuals sampled}

A total of 991 sea urchins was sampled over the period of a year, determined as 463 females, 491 males and 37 specimens of uncertain sex (due to the limited development of their gonads). For the 954 individuals sexed, the SR was 1.06 (Table 2).

Sea urchins sampled in intertidal and subtidal areas were larger than $3.5 \mathrm{~cm}$ in test diameter without spines, with a mean value of $51.75 \mathrm{~mm}$, ranging between 37.34 to $70.1 \mathrm{~mm}$ for all bathymetric levels (Table 2, Figure 2). Mean test height was $27.15 \mathrm{~mm}$ and with a range between 18.26 and $46.25 \mathrm{~mm}$. The mean weight was $19.07 \mathrm{~g}$, with a range between 8.12 and $40.82 \mathrm{~g}$. The diameter (Dt), height (Ht) and dry mass of the test (Mdt) were higher for subtidal specimens, with a wide variability (Figure 2). The p-values of the Wilcoxon-Mann-Whitney test were significantly different at $\alpha=0.05$. Our results indicate that the means of these features differed between intertidal and subtidal specimens (Table 2).

\subsection{Evolution of biological indices}

\subsubsection{Gonadosomatic Index (GI)}

The correlation coefficient used to compare the two GI values is close to $1\left(r^{2}=0.99\right)$ for intertidal and subtidal sectors. This means that they are more or less identical. For the intertidal level, the GI increased from September 2013 to April 2014 (Figure 3A), and then stabilised until late May. The index dropped off sharply until late June, when the temperature reached $17^{\circ} \mathrm{C}$. The index then increased until early July, to decrease again at the end of August 2014.

For the subtidal level, the GI showed the same trends as in the intertidal level but with higher values.

A slight difference between the two levels appeared beginning in May when the index fell earlier in the subtidal zone (early May) and later in the intertidal zone (late May), suggesting early gamete release.

The GI was always higher in the subtidal than in the intertidal area, with the exception of a period after spawning, between May and June and July and August. During the year, the GI followed different 
trends in both zones (Wilcoxon paired test $\mathrm{p}$-value $=0.1909$ ), probably reflecting the drop off in May for the intertidal zone and later for the subtidal zone at the end of June.

\subsubsection{Repletion index (RI)}

As seen for the GI, the correlation coefficient comparing the two RI values was close to $1\left(\mathrm{r}^{2}=0.98\right.$ in intertidal and $\mathrm{r}^{2}=0.94$ for subtidal). The RI showed the same tendencies between intertidal and subtidal areas (Figure 3B). At the intertidal level, the RI presented a very high variability between samples from September 2013 to August 2014 and the results of Wilcoxon paired test showed the same evolution between the two bathymetric levels ( $\mathrm{p}$-value $=0.0012)$. A strong decrease in the index was observed in October 2013 and between May and June 2014. The RI fluctuated more in the intertidal areas than in the subtidal ones.

The subtidal data showed an increase in the RI between September 2013 and April 2014, followed by a decline in May and a stabilisation from June to July. The index then decreased from late July to late August 2014.

The RI was higher in the intertidal than in the subtidal area, with two exceptions: in October and June. Application of the Welch test on these data gave a significant $p$-value ( $p$-value $=<2.2 e-16$, Table 3 ) meaning that the RI differed between the two tidal levels.

\subsubsection{Coevolution of the indexes}

The curves showing changes in GI and RI over time clearly show that there are links between these indexes (Figure 4), but also highlight the link between the simultaneous drop in the gonad index and water temperature.

However, the coevolution of the indexes was disturbed during the reproduction period, which changed general trends. Both indices followed the same trends for the subtidal level from October 2013 to April 2014. In May, the RI decreased when the GI was at its maximum and then increased in June when the GI was greatly reduced. The RI then stabilised until late July to late August, followed by a decrease, while the GI increased until the end of June and decreased until the end of August 2014. For the intertidal level, the two indices followed the same trends, but with a greater variability for RI. 
Application of the Welch test to these data gave a non significant $p$-value, for the intertidal ( $p$-value $=$ $0.67)$ as well as for subtidal level ( $\mathrm{p}$-value $=0.02)$. Throughout the period, the two means showed no significantly different patterns.

\section{Discussion}

The size of sea urchins at sexual maturity is highly dependent on their location and the environmental conditions they are exposed to. Sites of colonisation, as well as trophic conditions of individuals, seem to be very relevant to the maturity process. The choice to set the minimum test diameter for reproduction of $P$. lividus at $35 \mathrm{~mm}$ is based on the work of Sanchez-España et al. (2004) and Ouréns et al. (2011), who showed a significant difference in gonadosomatic indices around this size $(+/-1 \mathrm{~cm})$.

On the Basque French coast, the part of the stock fished is limited to a size greater than $4 \mathrm{~cm}$ (de Casamajor et al., 2014).

More recently, Garmendia et al. (2010) tested different indices, although they ultimately used the same index used in previous work; namely, the dry gonadal weight/dry weight of the test multiplied by 100 (Menchaca et al., 2011). After some tests with the indexes used in the literature (Byrne, 1990, Martinez et al., 2003, Ouréns et al., 2011, Ouréns et al., 2012), we chose to multiply by the diameter cubed, as the results appear more relevant given the spherical nature of the sea urchin test.

\subsection{Seasonality of spawning}

In the Atlantic, only one spawning peak is observed, which is in spring (Ouréns et al., 2011). For the Spanish Basque coast, spawning takes place between April and May (Menchaca et al., 2011). Our results for the French Basque coast show that gametes are released later, in May and June, but that reproduction also takes place in spring. This seasonality of spawning is a very important factor in the literature on this species (Table 3). For the Atlantic population, latitude is important, as it is for many marine invertebrates, but other environmental factors can also explain the breeding time (Brewin et al., 2000). Analysis of sequence variation of a fragment of a mitochondrial gene (cytochrome c oxidase) divided P. lividus into two geographic populations: the Mediterranean and the Atlantic (Duran et al. 2004). Analysis of cytochrome b identified a third population in the Adriatic Sea (Maltagliati et al., 2010). In the Mediterranean sea, the available information shows two peaks of spawning: one in the 
spring and the other in autumn (Régis, 1979; Guettaf, 1997; Martinez et al., 2001; Leoni et al., 2003). More recently, however, Gianguzza et al. (2013) found no peaks during the breeding season but instead noted a gradual decrease in the index. The present study highlights the seasonal gonadal growth from September to March for both bathymetric levels. This growth increased rapidly between March and April and is typical of the Atlantic population, unlike that of the Mediterranean population which is very irregular (Ourens et al., 2011).

Environmental factors may vary from one year to another and shift the spawning period. Consequently, this late spawning (May and June) may have resulted from the environmental conditions in 2014. This definitely points to a need to improve the level definition of gonad development in order to understand the spawning period on the French Basque coast. We should compare the changes in the gonad index across one year and compare this with water temperature changes.

Temperature is also an important seasonal parameter in gonad maturation for sea urchins (Bronstein \& Loya, 2015). An increase in the water temperature has been identified as a cause of gonad maturation and gamete release, with an optimum between 18 and $22{ }^{\circ} \mathrm{C}$ reached in June (Figure 4). However, the input of water discharge also may have an impact on the maturation process. The occurrence of a period of high planktonic productivity was identified as important for the process of gonadal maturation of the sea urchin (Zhadan et al., 2015), but this parameter was not followed in the present study.

The present investigation was carried out over only one season. To consider these results as valid for the site in general, the possible occurrence of significant fluctuations related to inter-annual variability of environmental conditions must be taken into account. This means that sea urchins can reproduce with a delay, based on the comparison of our observations in the season depending on weather conditions; these results should be considered with caution in terms of precise seasonality of the cycle (Epherra, et al., 2015, Hernandez et al., 2011). Thus, repeating this sampling design in other years would be interesting to confirm these observations and to assess the variability of the spawning period during the season. However, the extensive bibliography on the reproduction process of sea urchins 
271 indicates a high sensitivity of this species to environmental conditions (Ouréns et al., 2011; Ouréns et

272 al., 2013).

273 4.2. Influence of bathymetric levels

274 Byrne (1990) compared intertidal and subtidal sea urchins at different levels of habitat exposure in 275 Ireland, but chose two different places where environmental conditions differed. Individuals living in 276 the intertidal zone are subjected to much greater fluctuations (like temperature, salinity, etc.) than 277 those living in the subtidal area. Other characteristics of the Basque coast, compared with other 278 studied areas, are the very high wave action and the high flood events occurring during the spring.

279 The main environmental differences between the two tidal levels are the exposure of intertidal zone to changes in environmental conditions associated with alternating periods of immersion and emersion.

281 Byrne (1990) showed that sea urchins were larger in the subtidal zone than in intertidal areas. The 282 subtidal sea urchins also had larger gonads and displayed a longer period of reproduction than intertidal specimens. Our results confirm these observations regarding the diameters of sea urchins, gonadal indices and changes over the sampling period (Figures 2 and 4). However, our work is not readily comparable with that of Byrne (1990), since we sampled habitats with the same hydrodynamic conditions and only bathymetric level differences. By contrast, Byrne used different levels of exposure in the intertidal and subtidal sampling sites.

The amount of available food, considering trophic limitations in intertidal areas, may explain the differences observed (Ebert, 1996). Moreover, hydrodynamic conditions could induce sea urchins to spend more energy on spine reconstitution than on gonads. Furthermore, the larger intertidal

291 individuals are subject to fishing pressure. Sea urchins in these areas may not have time to develop and 292 reach large diameters. Movement of adults toward subtidal environments may also occur (BarilléBoyer et al., 2004), but was be monitored in this work. Confirmation of these movements would require an appropriate method of tagging (Dumont \& Himmelman, 2008).

295 The subtidal and intertidal zones are differentiated by the size of the individuals that occupy them. The repletion index fluctuates more and is higher during winter in intertidal sites than in subtidal sampling 
site. Food intake likely has a significant role in the differences observed between the two bathymetric zones. A positive relationship between the size of the test and gonads has been described for echinoids (Sellem et al., 2007). Thus, subtidal gonads are larger than those of the intertidal zone. Logically, the opposite phenomenon is observed for the index of repletion. Subtidal sea urchins will hold more gametes and therefore have a greater capacity than their intertidal counterparts. However, gonadal indices obtained for both bathymetric zones have similar seasonal values. Synchronized exchange between the urchins of the two bathymetric zones is possible, since they constitute part of the same population. The density of individuals on the Basque coast is low and not a limiting factor for the growth of individuals as there is no trophic competition here (Ouréns et al., 2013; de Casamajor et al., 2014). In addition, temperature and salinity can affect individuals by reducing the growth rate, thereby causing a decrease in the gonadosomatic index (Fernandez et al., 2001; Basuyaux et al., 1998).

\subsection{Hydrodynamics and food availability}

Food availability, in terms of quantity as well as quality, is a very important factor in explaining phenotypic plasticity (Ebert, 1996). Wave exposure is well known to play a key role in determining patterns of distribution and abundance of marine organisms, mainly in coastal habitats and for benthic organisms (Lindegarth \& Gamfeldt, 2005). Hydrodynamic conditions can limit the growth and gonadal maturation of the sea urchin population (Meidel \& Scheibling, 1998; Jacinto et al., 2013). Occupation of burrows might be an adaptive behaviour that allows sea urchins to avoid limiting their energy expenditure (Jacinto \& Cruz, 2012). The French Basque coast is well known as a particularly wave-exposed coast (Abadie et al., 2005).

Sea urchins on the French Basque coast can mobilise more energy to resist wave impacts than can sea urchins of the Spanish Basque coast. Due to high phenotypic plasticity, urchins exposed to the swells use more energy to resist the wave forces and to burrow. Therefore, they have a lower ability to feed themselves. For this reason, they are expected to take much more time to metabolise gonads.

This work shows a seasonal shift in the release of gametes between intertidal and subtidal sea urchins, where intertidal sea urchins have a higher index of repletion than do subtidal ones and conversely their 
323

gonadosomatic index is lower. This result could be explained by the fact that they need more food to mobilise energy for maturation of their gonads than do specimens in the subtidal area because they have to fight against the hydrodynamics and expend energy maintaining their spines (Moureaux et al., 2010). In intertidal areas, with high-energy waves, sea urchins favour capturing elements in suspension rather than grazing algae for food (Riquelme et al., 2013). During low tide, the quantity of suspended matter decreases and may be a factor limiting the size development of sea urchins (Gago et al., 2003). These trophic modalities do not allow intertidal sea urchins to reach a gonadosomatic index as high as those achieved by subtidal ones. This difference in gamete productivity must be taken into account in sea urchin stock management, and this work suggests that the subtidal sea urchins are more productive than those colonising intertidal areas.

This work provides new information about sea urchins of the French Basque coast that has been lacking thus far.. This information provides useful elements for the managers to use to define conservation measures (duration of the fishing season, spatial considerations, etc.). Sampling during only one year is not sufficient to consider the inter-annual variability of environmental conditions. Therefore, completion of this work should include new sampling campaigns to improve comprehension of the interaction of environmental conditions on processes related to reproduction of the sea urchin in this area. Further histological analyses on gonads and on stomach contents would provide additional information on the behaviour of individuals in this particular area, which is subjected to the strongest swells on the Atlantic coast.

\section{Acknowledgments}

This work used data from the ARISTOT project, which was realized under the aegis of the CIDPMEM 64/40 with financial support from Europe, State, Aquitaine region and département of PyrénéesAtlantiques as part of Axis 4 European Fisheries Fund.

We thank all the people and structures that contributed to the success of this study, from field sampling, dissection and laboratory work to mapping and proofreading this document. Many thanks to the University of Pau and Pays de l'Adour, especially for allowing us access to the 
350 laboratories of the Anglet Faculty of Science and Technology. Finally, we thank AZTI for allowing us

351 to benefit from their experience on sampling of this species on the Spanish Basque coast. 


\section{References}

Abadie, S., Butel, R., Dupuis, H., Brière, C., 2005. Paramètres statistiques de la houle au large de la côte sud-aquitaine. C.R. Geoscience, 337:769-776.

Augris, C., Caill-Milly, N., Casamajor (de), M.N., 2009. Atlas thématique de l'environnement marin du Pays basque et du sud des Landes. Ed. Quae, Brest, 90 p.

Bald, J., Borja, A., Garmendia, J.M., Rodríguez, J.G., Galparsoro, I., 2007. Evaluación de la biomasa submareal de erizo y anémona entre el municipio de Elantxobe y el Cabo de Santa Catalina (Bizkaia, País Vasco) : un análisis para su futura explotación y gestión. 351BI20070011. Informe inédito para la direccíon de Pesca y Acuicultura del Gobierno Vasco, 102 p.

Barillé-Boyer, A.L., Gruet, Y., Harin, N., Barillé, L., 2004. Temporal changes in community structure of tide pools following the «Erika » oil spill. Aquat. Living Ress. 17 : 323-328.

Bassuyaux, O., Mathieu, M., Day, C., 1998. Effet de la salinité sur la consommation alimentaire et sur la croissance de l'oursin Paracentrotus lividus et de l'ormeau Haliotis tuberculata en élevage en circuit fermé. Bull. de la Soc. Zool. de Fr., 123: 141-150.

Boudouresque, C.F., Verlaque, M., 2013. Paracentrotus lividus. In Lawrence J.M. 3rd edition, Elseviers Sea Urchins: Biology and Ecology, Developments in Aquaculture and Fish. Sci., 38: 297-319.

Brewin, PE., Lamare, MD., Keogh, J.A., Mladenov, P.V., 2000. Reproductive variability over a 4 year period in the sea urchin Evechinus chloroticus (Echinoidea: Echinometridae) from differing habitats in New Zealand. Mar Biol 137:543-557.

Briand, D., 1995. Suivi de captures d'oursins prélevés sur la côte est de Miquelon Langlade. Rapport Ifremer, $2 \mathrm{p}$.

Bronstein, O., Loya, Y., 2015. Photoperiod, temperature, and food availability as drivers of the annual reproductive cycle of the sea urchin Echinometra sp. from the Gulf of Aqaba (Red Sea). Coral reefs, 34:275-289. 
Byrne, M., 1990. Annual reproductive cycles of the commercial sea urchin Paracentrotus lividus from an exposed intertidal and a sheltered subtidal habitat on the west coast of Ireland. Mar. Biol, 104 :275-289.

Casamajor, (de) M.N., Mahias, J., Bru N., Caill-Milly, N., 2014. Analyse des ressources et des caractéristiques individuelles du stock d'oursin Paracentrotus lividus (Lamarck, 1916) du territoire 64., Rapp. Int. Ifremer, RBE/HGS/LRHA 14-004, 46p + annexes. http://archimer.ifremer.fr/doc/00218/32889/

Dumont, C.P., Himmelman, J.H., 2008. Le comportement de déplacement de l'oursin vert. 132 (1): $68-74$.

Duran, S., Palacin, C., Becerro, M., Turon, X., 2004. Genetic diversity and population structure of the commercially harvested sea urchin Paracentrotus lividus (Echinodermata, Echinoidea). Mol. ecol. 13: 3317-3328.

Ebert, A., 1996. Adaptative aspects of phenotypic plasticity in echinoderms, Oceanologica acta, 19:3-4 Epherra, L., Gil, DG., Rubilar, T., Perez-Gallo, S Reartes, M.B., Tolosano, JA. 2015. Temporal and spatial differences in the reproductive biology of the sea urchin Arbacia dufresnii. Mar. and Freshwater Research 66: 329-342.

Fernandez, C., Caltagirone, A., 1998. Comportement alimentaire de Paracentrotus lividus (Echinodermata: Echinoidea) en milieu lagunaire. Rapp. Comm. Int. Mer. Medit., 35, 538-539.

Fernandez, C., Pascalini, V., Johnson, M., Ferrat, L., 2001. Stock evaluation of the sea urchin Paracentrotus lividus in a lagoonal environment. Echinoderme Research, 319-322.

Gago, J., Range, P., Luis, O.J., 2003. Growth, reproductive biology and habitat selection of the sea urchin Paracentrotus lividus in the coastal waters of Cascais, Portugal. In: J. P. Fe'ral \& B. David, editors. Echinoderm research 2001. Lisse: A.A. Balkema, pp. 269-276.

Gianguzza, P., Bonaviri, C., Prato, E., Fanelli, G., Chiantore, M., Privitera, D., Luzzu, F., Agnetta D., 2013. Hydrodynamism and its influence on the reproductive condition of the edible sea urchin Paracentrotus lividus. Mar. Env. Research, 85 : 29-33. 
Gonzáles-Irusta, J.M., Goñi de Cerio, F., Canteras, J.C., 2010. Reproductive cycle of the sea urchin Paracentrotus lividus in the Cantabrian sea (northern Spain): environnemental effects. Journal of the Marine Biology Assoc. of the U. K., 90 : 699-709.

Grosjean, P., 2001. Growth model of the reared sea urchin Paracentrotus lividus (Lamark, 1816). Rapport de l’Université libre de Bruxelles, 178 p.

Guettaf, M., 1997. Contribution à l'étude de la variabilité du cycle reproducteur (indice gonadique et histologie des gonades) chez Paracentrotus lividus (Echinodermata: Echinoidea) en Méditerranée sud occidentale (Algérie). Thèse de Doctorat en Océanologie, Université d'Aix Marseille II, France., 132 p.

Hernández JC, S Clemente \& A Brito. 2011. Effects of seasonality on the reproductive cycle of Diadema aff. antillarum in two contrasting habitats: implications for the establishment of a sea urchin fishery, Mar Biol, 158: 2603-2615.

Jacinto, D., Bulleri, F., Benetti-Cecchi L., Cruz T., 2013. Patterns of abundance, population size structure and microhabitat usage of Paracentrotus lividus (Echinodermata:Echinoidea in SW Portugal and NW Italy., Mar. Biol., 160:1135-1146.

Jacinto, D., Cruz T., 2012. Paracentrotus lividus (Echinodermata: Echinoidea attachment force and burrowing behavior in rocky shores of SW Portugal. Zoosymposia 7: 231-240.

King, CK., Hoegh-Guldberg, O., Byrne, M. 1994. Reproductive cycle of Centrostephanus rodgersii (Echinoidea), with recommendations for the establishment of a sea urchin fishery in New South Wales. Mar. Biol., 120:95-106.

Leoni, V., Fernandez, C., Johnson, M., Ferrat, L., Pergent-Martini C., 2003. Preliminary study on spawning periods in the sea urchin Paracentrotus lividus from lagoon and marine environments, in: Féral, J.-P. et al. (2003). Echinoderm Research 2001: proceedings of the 6th European Conference on Echinoderm Research, Banyuls-sur-mer, 3-7 September 2001. pp. 277-280.

Lindegarth, M., Gamfeldt, L., 2005. Comparing catgorical and continous ecological analyses: effects of "wave esposure" on rocky shore. Ecol., 86(5):1346-1357. 
Maltagliati, F., Di Giuseppe, G., Barbieri, M., Castelli, A., Dini, F., 2010. Phylogeography and genetic structure of the edible sea urchin Paracentrotus lividus (Echinodermata: Echinoidea) inferred from the mitochondrial cytochrome b gene. Biol. J. of the Linnean Soc., 100, 910-923.

Martinez, I., Garcia, F.J., Sanchez, A.I., Daza, J.L., del Castillo, F., 2001. Biometric parameters and reproductive cycle of Paracentrotus lividus (Lamarck) in three habitats of Southern Spain. Echinoderm. Research., Féral \& David (eds.), 281-287.

Meidel, S.K., Scheibling, R.E., (1998) Annual reproductive cycle of the green sea urchin, Strongylocentrotus droebachiensis, in differing habitats in Nova Scotia, Canada. Mar. Biol. 131:461-478.

Menchaca, I., Belzunce, M.J., Franco, J., Garmendia, J.M., 2011. Investigation on the annual availability of gametes in two populations (south-eastern Bay of Biscay, Spain) of the sea urchin Paracentrotus lividus (Lamarck, 1816) for toxicity tests. AZTI-Technicalia , Revista de Investigación Marina, 18(3) : 38-44.

Moureaux, C., Perez-Huerta, A., Compere, P., Zhu, W., Leloup, T., Cusack, M., Dubois, P., 2010. Structure, composition and mechanical relations to function in sea urchin spine. J. of structural biol., 170.1: 41-49.

Ouréns, R., Fernández, L., Juan. F., 2011. Geographic, population, and seasonal patterns in the reproductive parameters of the sea urchin Paracentrotus lividus. Mar. Biol, 158: 793-804.

Ouréns R., Flores L., Fernández L., Freire J., 2013. Habitat and density-dependent growth of the sea urchin Paracentrotus lividus in Galicia (NW Spain). J. of Sea Research, 76: 50-60. doi: 10.1016/j.seares.2012.10.011 .

Ouréns R., Freire J., Fernández L., 2012. Definition of a new unbiased gonad index for aquatic invertebrates and fish: its application to the sea urchin Paracentrotus lividus. Aqua. Biol., 17: 145-152. doi: 10.3354/ab00476.

Pearse, J.C.,1970. Reproductive periodicities of Indo-Pacific invertebrates in the Golf of Suez. III. The echinoid Diadema setosum (Leske). Bull. Mar. Sci., 20: 697-720.

Régis, M.B., 1980. Étude des possibilités d'élevage des oursins réguliers en fonction de la valeur de certains indices physiologiques. Océanologica acta, vol. 3, num. 1, 9 p. 
Régis, M.B., 1979. Analyse des fluctuations des indices physiologiques chez deux echinoids (Paracentrotus lividus (Lmk) et Arbacia lixula L.) du Golfe de Marseille. Tethys. 9: 167-181.

Riquelme, F., Bald, J., Galparsoro, I., Liria, P., Menchaca, I., Rodriguez, J.G., 2013. Análisis de la idoneidad del hábitat del erizo de mar (Paracentrotus lividus) en el litoral del País Vasco. AZTI-Technicalia, Revista de Investigación Marina, 20 (9): 149-163.

Sanchez-Espana, A., Martinez-Pita, I., Garcia, F., 2004. Gonadal growth and reproduction in the commercial sea urchin Paracentrotus lividus (Lamarck, 1816) (Echinodermata: Echinoidea) from southern Spain. Hydrobiologia 519.1-3: 61-72.

Shpigel, M., McBride, S.C, Marciano, S., Lupatsch, I., 2004. The effect of photoperiod and the temperature on the reproduction of European sea urchin Paracentrotus lividus. Aquac. 232: $342-355$.

Sellem, F., Guillou, M., 2007. Reproductive biology of Paracentrotus lividus (Echinodermata, Echinoidea) in two contrasting habitats of northern Tunisia (southeast Mediterranean). J. of the Mar. Biol. Assoc. of the U. K., 87: 763-767.

Spirlet, C., Grosjean, P., Jangoux, M., 2000. Optimization of gonal growth by manipulation of temperature and photoperiod in cultivated sea urchins, Paracentrotus lividus (Lamarck) (Echinodermata), Aquaculture, 185: 95-99.

Usabiaga, J.I., Aguirre, J.S., Valencia V., Borja, A., 2004. Climate and Meteorology: variability and its influence on the ocean. In Oceanography and marine environment of the basque country. Ed. Borja and Collins: 75-95.

Winckel, A., Petitjean, J. Borie, M., Mallet, C., Aubié S., 2004. État des connaissances hydrologiques et hydrogéologiques de la côte basque. BRGM/RP-53372-FR, 113 p. 45 illustrations, 5 annexes.

Zhadan, P.M., Vaschenkob, M. A., Almyashova, T. N., 2015 Spawning failure in the sea urchin Strongylocentrotus intermedius in the northwestern Sea of Japan: Potential environmental causes. J. of Exp. Marine Biol. and Ecol., 465: 11-23. 


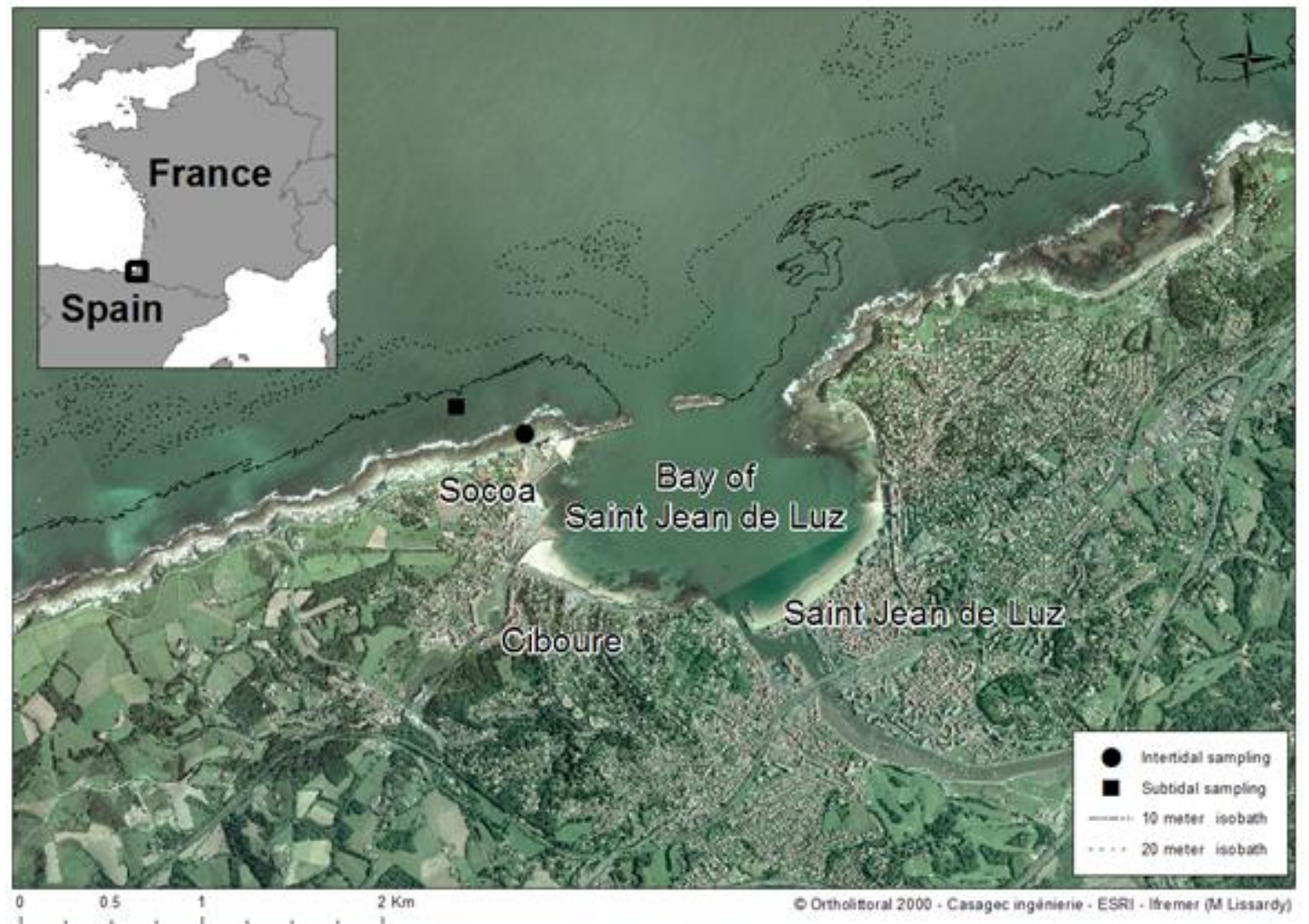

Figure 1: Geographical situation of the sampling locations and positions of subtidal and intertidal stations used to study the Paracentrotus lividus reproduction cycle. 

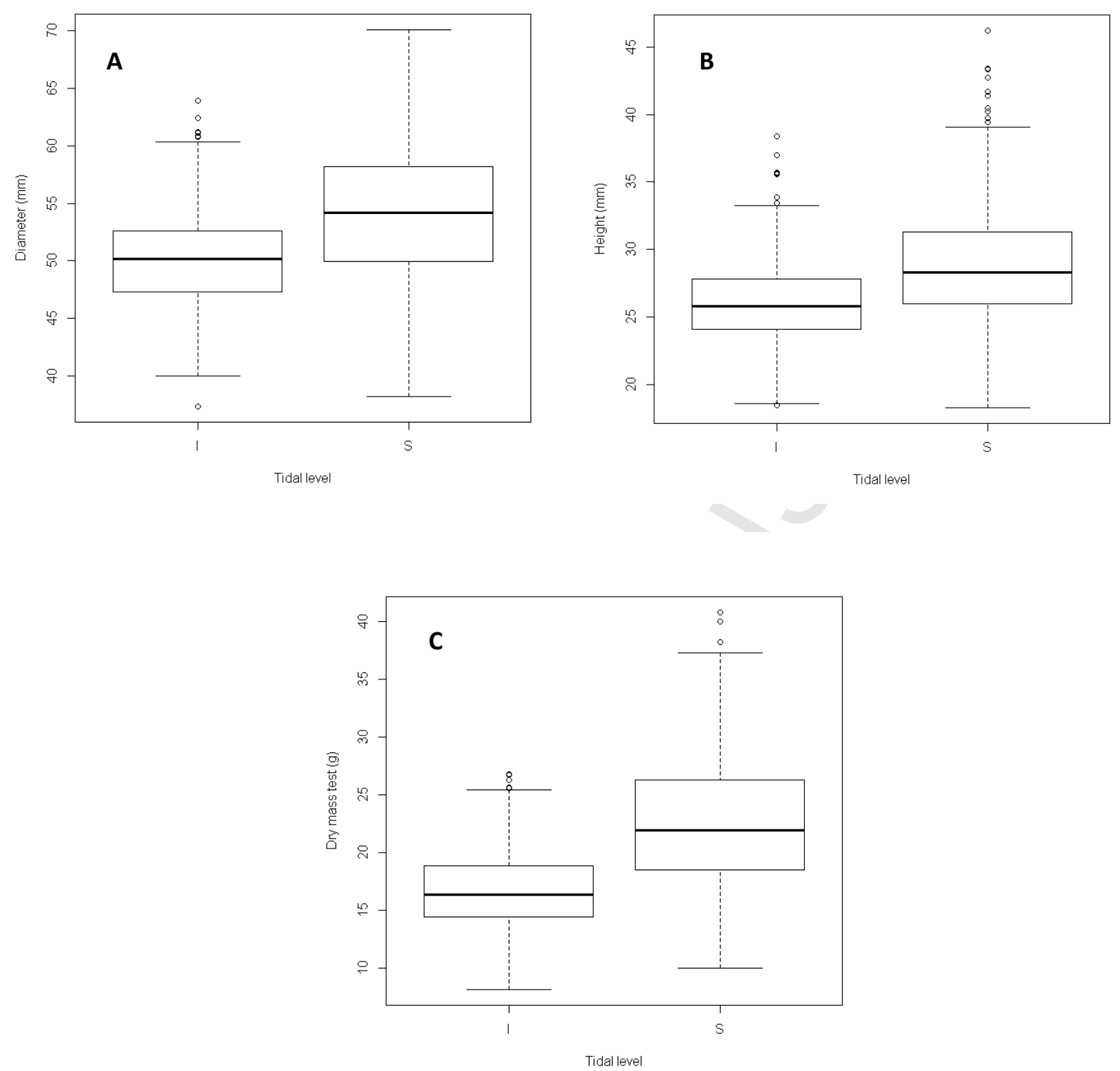

Figure 2: Box plots of the diameter (A), height (B) and dry mass of the test (C) for Paracentrotus lividus from two tidal levels (I and S). Horizontal lines within the boxes are the medians. The upper and lower limits of the boxes indicate the first and the third quartiles, respectivelty. The vertical lines indicate the highest (upper line) and lowest (lower line) values within 1.5 times the interquartile distance from the limits of the boxes. Values outside these limits are plotted with points. 
Table 1: Samples of Paracentrotus lividus taken between September 2013 and September 2014.

\begin{tabular}{|c|c|c|c|}
\hline Level & $\begin{array}{c}\text { Number of } \\
\text { samples }\end{array}$ & $\begin{array}{c}\text { Range } \\
\text { temperature } \\
\left({ }^{\circ} \mathrm{C}\right)\end{array}$ & $\begin{array}{c}\text { Range } \\
\text { Tidal } \\
\text { coefficient }\end{array}$ \\
\hline intertidal & 18 & $12-23$ & $75-111$ \\
\hline subtidal & $14^{*}$ & $12-22$ & $43-104$ \\
\hline
\end{tabular}

* no data for the subtidal area in January and February 2014 due to successive storms 
Table 2: Morphometric variables describing Paracentrotus lividus on the French Basque coast for the total sample population, the sample population in the intertidal zone and the sample population in the subtidal zone. Additional information on sea urchin sex ratio (SR) relative to bathymetric level.

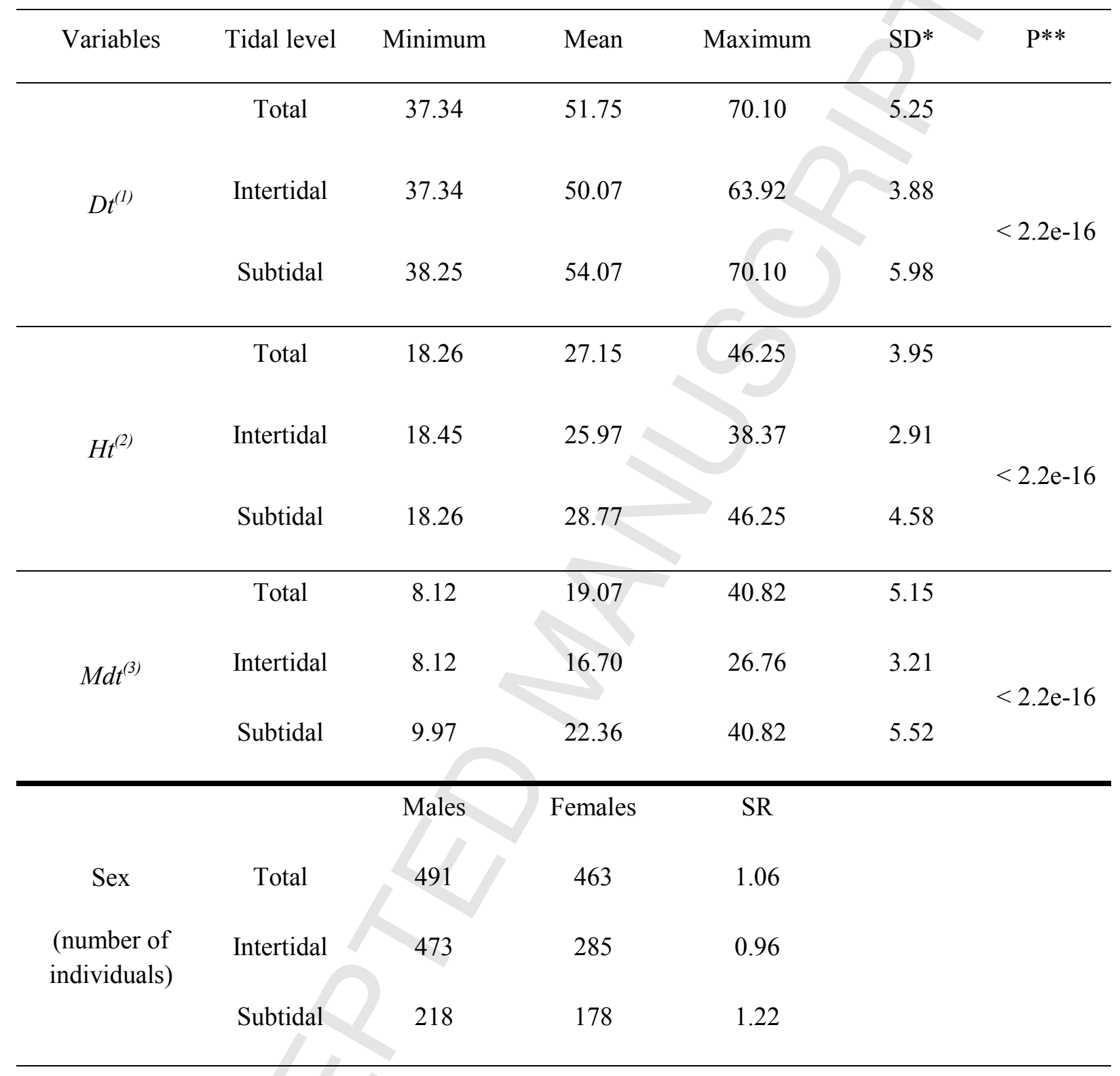

(1) Dt - diameter at ambitus; (2) Ht - height; (3) Mdt - dry mass of the test; * SD - standard deviation; ** P probability value using Wilcoxon-Mann-Whitney test. 

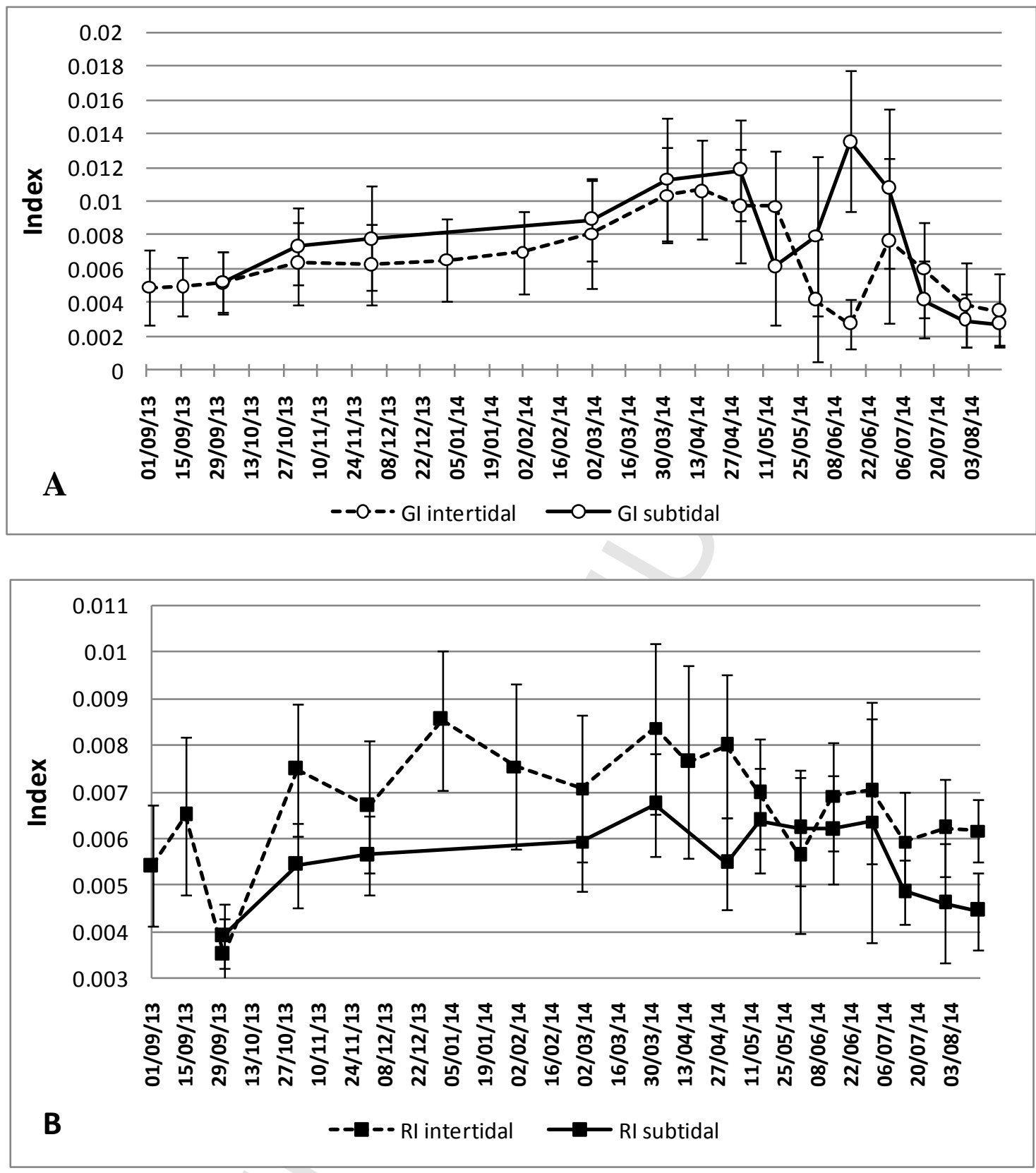

Figure 3A and B: Changes in gonadosomatic index (GI) and repletion index (RI) of Paracentrotus lividus at intertidal (dotted line) and subtidal (continuous line) levels. 

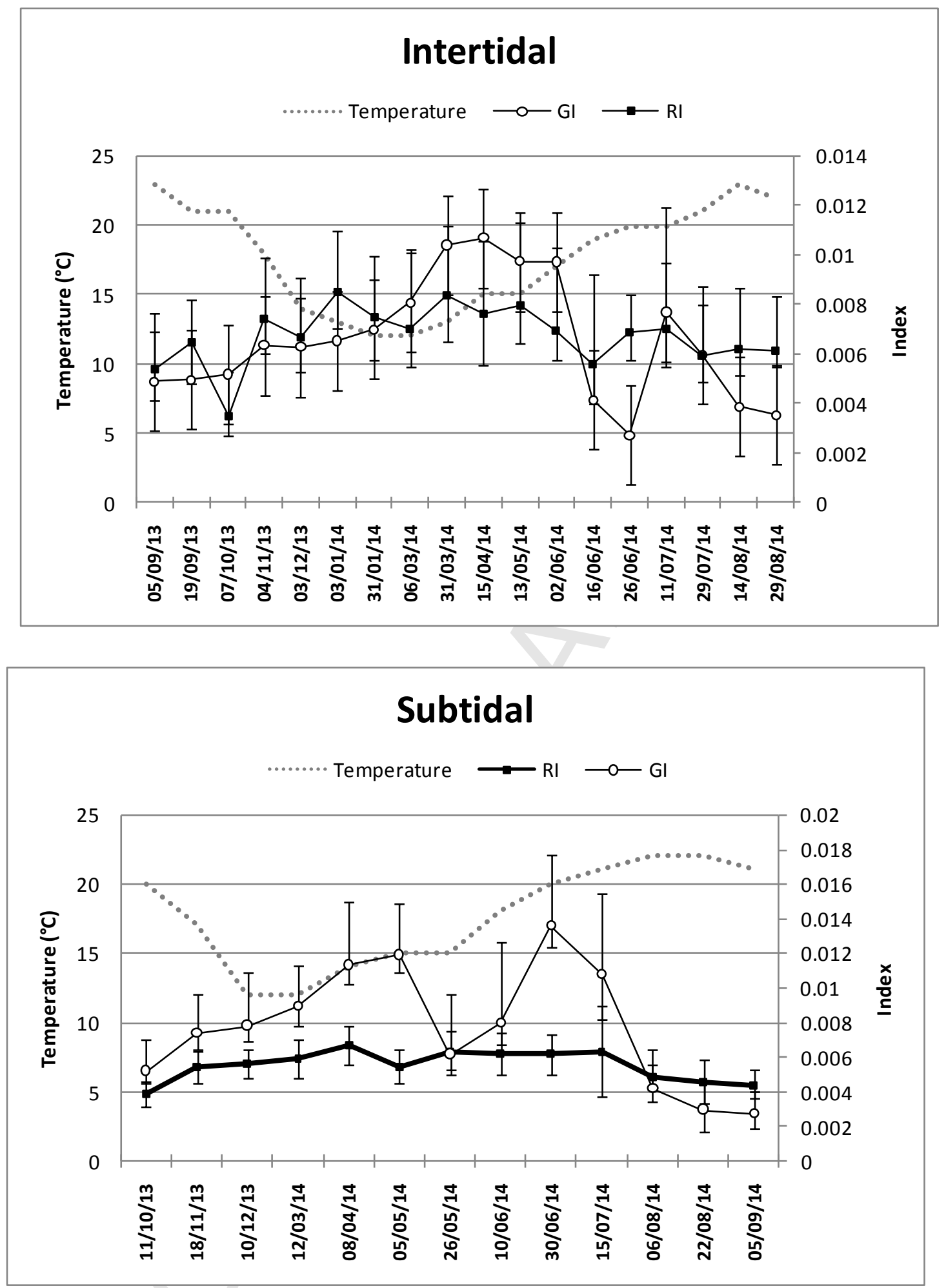

Figure 4: Comparaison of gonadosomatic index (GI) and repletion index (RI) of Paracentrotus lividus associated with sea water temperature (dotted line) at intertidal and subtidal levels. 
Table 3: Period(s) of spawning of Paracentrotus lividus.

\begin{tabular}{lccc}
\hline \multicolumn{1}{c}{ Location } & Number of spawning(s) & Dates of spawning & References \\
\hline Bantry Bay, Ireland & 2 & January to March & Crapp \& Willis (1975) \\
Basque coast, Spain & 1 & August-September & Garmendia et al. (2010) \\
Marseille, France & 2 & Septembre to November & Régis (1979) \\
El Marsa, Algeria & 2 & April & Guettaf (1997) \\
Basque coast, France & 1 & September-October & de Casamajor et al. (2014) \\
\hline
\end{tabular}

